\title{
LSE
}

LSE 'Europe in Question' Discussion Paper Series

\section{Transnational Partisanship and Networked Constituent Power in the EU}

Fabio Wolkenstein

LEQS Paper No. 138/2018 October 2018

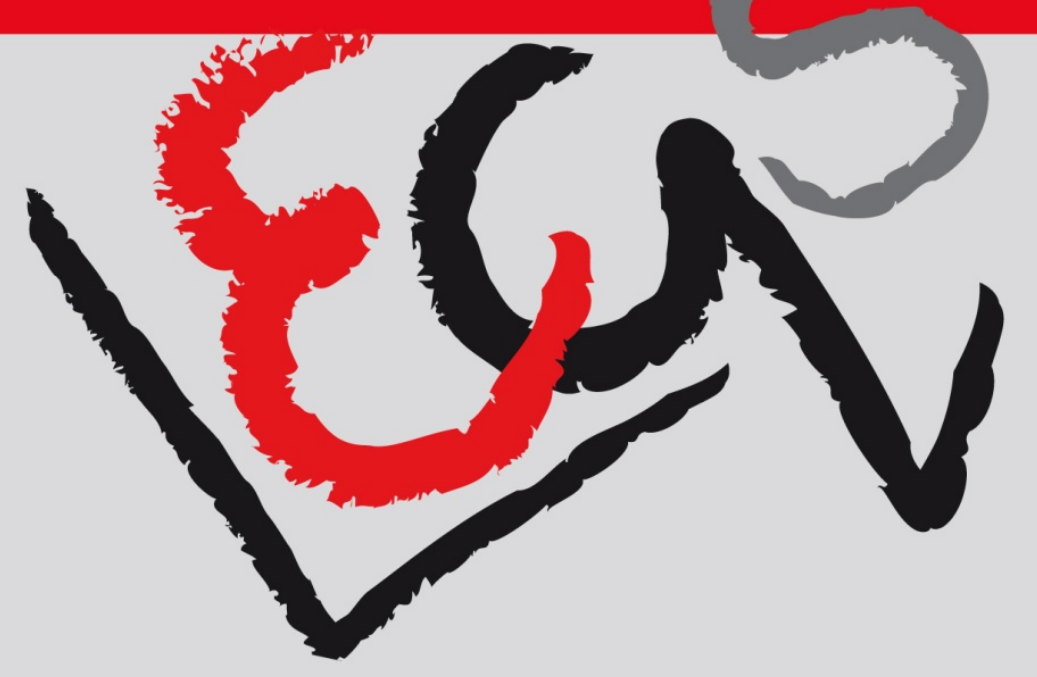




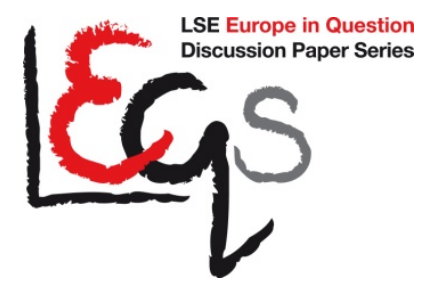

\author{
Editorial Board \\ Dr Bob Hancké \\ Dr Jonathan White \\ Dr Sonja Avlijas \\ Mr Sean Deel
}

All views expressed in this paper are those of the author and do not necessarily represent the views of the editors or the LSE.

(C) Fabio Wolkenstein

Eqs 


\title{
Transnational Partisanship and Networked Constituent Power in the EU
}

\author{
Fabio Wolkenstein *
}

\section{Abstract}

The constitutional politics of the European Union have been intensely debated in recent times. A key concern, voiced both within the academy and at street level, is how citizens could be endowed with the ability to shape, revise and legitimise evolving constitutional settlements. This paper begins by discussing recent accounts of 'constituent power' in the EU that seek to offer guidance in this respect. It argues that these accounts are normatively insightful but ultimately stop short of providing a viable model of constitutional agency. The remainder of the paper then aims to examine what such a model could look like, looking for inspiration to the muchneglected political practice of transnational partisanship. Specifically, the paper examines the transnationally coordinated constitution-making efforts of Christian Democratic partisans in the founding period of the EU, suggesting that there is much to learn from these efforts as far as EU constitutional politics is concerned.

Keywords: Transnational partisanship, constituent power, EU constitutionalism, Christian Democracy, Jürgen Habermas

* Aarhus University \& University of Amsterdam

Email:wolkenstein@ps.au.dk 


\section{Table of Contents}

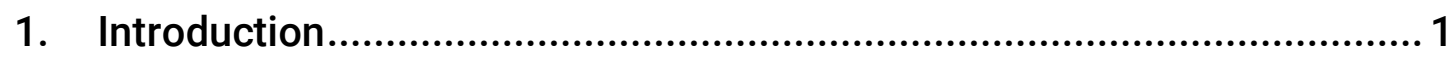

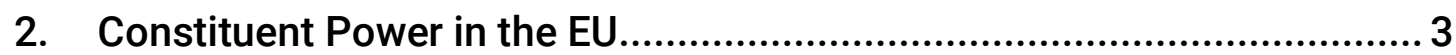

3. Transnational partisanship and constituent power.............................10

3.1 Organising constituent power: Partisan networks.............................. 12

3.2 Justifying and sustaining constituent power: The role of ideology ... 21

3.3 Constituent power without participation? ........................................26

4. Revisions to the Christian Democratic model .....................................29

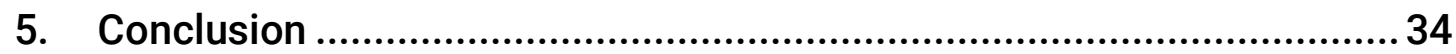

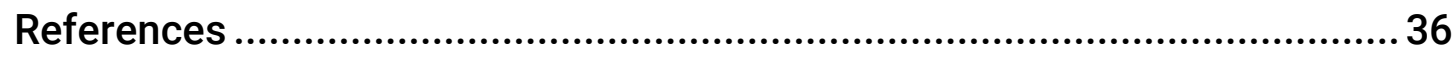

\section{Acknowledgments}

For helpful comments on previous drafts I thank Markus Patberg, Signe Larsen, Roman Senninger, Göran Duus-Otterström, Søren Midtgaard, Tore Vincents Olsen, Andreas Albertsen, Nenad Stojanovic, and the participants of the workshop on the "EU and Ideologies" at the ECPR Joint Sessions 2018 in Nicosia, especially Dimitris Efthimiou, Hjalte Lokdam, Jonathan White and Carlo Invernizzi-Accetti.

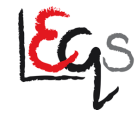




\section{Transnational Partisanship and Networked Constituent Power in the EU}

\section{Introduction}

The constitutional politics of the European Union have been intensely debated in recent times. One widespread perception animating the debate is that the constitutionalisation of the EU polity has taken place in a largely apolitical fashion, in a process driven by decisions of courts, notably the Court of Justice of the EU (CJEU), that are taken in isolation from political contestation and popular participation (e.g. Glencross 2014; Grimm 2015; Scharpf 2017). This has led to increased calls for the politicisation of the EU constitutional order (e.g. Fabbrini 2016; Glencross 2014; Niesen 2017). Accordingly, citizens should be endowed with the ability to shape, revise and legitimise evolving constitutional settlements.

This view is not only voiced within the academy. Analogous concerns have also been expressed at the street level, perhaps most prominently in the panEuropean movement DiEM25. DiEM's express ambition is to establish a European constituent assembly, in which the citizens of Europe should deliberate on how to transform the EU into a 'full-fledged democracy' 
(DiEM25, 2017). The goal is to transform the citizens of Europe into a constituent power capable of revising the constitutional features of the EU at large.

The normative logic underpinning these scholarly and activist perspectives is as old as modern democracy itself: if the EU is to be a democratic constitutional order, then its citizens must be the source of that order, and the subjects with whom sovereignty ultimately rests (Habermas 2011; Cohen 2012). But how exactly should we think of constituent power in the EU? It is one thing to stress the importance of enhanced constitutional agency, and quite another to provide a model of how constitutional agency can and should be exercised.

As a response to this question, a small number of political and legal theorists have recently elaborated sophisticated accounts of constituent power in the EU that are intended to resolve these complex normative and conceptual issues (Cheneval 2011; Crum 2012; Habermas 2011; Niesen 2017; Patberg 2017; von Achenbach 2017). In this paper, I begin by outlining these accounts. I suggest that there are good reasons to favour accounts of 'mixed' constituent power, as defended by Jürgen Habermas (2011) and others, over ones that see constituent power as resting solely with the peoples of EU member states. However, I also show that existing accounts of that kind are inadequate, inasmuch as they under-theorise how real-world citizens can come to act as constituent power in the first place.

The remainder of the paper then aims to explore how the abstract principles of pouvoir constituant mixte may be connected to political practice. I look for inspiration to a much-neglected political practice - transnational partisanship. Drawing on the case of Christian Democratic transnationalism, I specifically discuss how partisan networks honed by like-minded political activists and elected representatives from different European states have provided the 
backbone for Christian Democrats' successful exercise of supra-state constituent power. This distinctive mode of cross-border organisation and coordination helps imagine how today's citizens can engage as agents of EU constitutional politics.

Although the model of partisanship-driven 'networked constituent power' has many attractive features, and has been proven to be in principle feasible, it cannot be adopted without modifications. Three revisions are central, I suggest: contrary to the Christian Democratic reliance on elite-driven politics, contemporary transnational partisan networks aimed at exercising constituent power must be open to citizen participation; contrary to Christian Democratic practice in the post-war years, they must be ready to submit actions to public approval; and in contrast to the Christian Democratic insistence on religious establishment, they must develop a more inclusive justificatory rationale for their constitutional agenda.

In sum, the paper argues that there is much to learn from Christian Democratic transnationalism when it comes to the exercise of constituent power in the EU - first because it offers a promising general model for organising and coordinating constitutional agency, and second because reflecting on its less attractive features permits us to see which mistakes are to be avoided in future efforts to politicise the EU constitutional order.

\section{Constituent Power in the EU}

A polity can be considered democratic if power vests ultimately in 'the people.' This is the essence of the modern doctrine of popular sovereignty that underpins most democratic constitutional orders. The people of a democratic polity is accordingly ascribed the status of constituent power - the agent to 
whose will the original constitution can be traced and who retains the authority to decide all issues of constitutional design. This means that the people are endowed with two powers: the power to legitimately bring a democratic constitutional order into existence, and the power to reform its foundational norms and rule as they see fit (see Arato 2016; Böckenförde 2006; Kalyvas 2005; Loughlin 2014).

On the face of it, it is difficult to make sense of this concept in the context of the European Union (Walker 2007). For the EU is not a democratic federal state with a central constitutional document that can in some relevant sense be seen as the product of 'the people,' but a supranational polity that has developed from a relatively loose association of nation states into a constitutional order comprising of multiple member states (on the nation state/member state distinction, see Bickerton 2012; on EU constitutionalisation, see Grimm 2015). Who might in this polity be the agent to whom the ultimate authority to decide constitutional issues can be attributed, and who is thus responsible for enacting constitutional reform and revision?

Two different responses to that question have emerged in the recent political theory literature. The first assumes that the EU is 'not constituted by a single people or "demos"' (Crum 2012: 45) but that it has 'several pouvoirs constituants,' namely the demoi of the member states (Cheneval et al. 2015: 4; Cheneval 2011). Authors defending this sort of position follow broadly Rawlsian argumentative strategies, invoking such devices as an 'original position' and 'public reason,' and suggest that decisions about EU constitutional design ought to be determined by the member states' peoples. As Cheneval et al. (2015: 4) write, 'sovereign decisions' such as treaty 
ratifications 'are to be taken by or [must be] directly accountable to the pouvoir constituant of the states which are the citizens organized as People.'

Different conclusions have been drawn concerning this account's implications for the politicisation of the EU constitutional order. Some scholars take it to imply that the member states' peoples must participate in a direct and unmediated fashion in EU constitutional politics (Cheneval 2011: 133-137). Other authors accept that constitutional decisions of this sort may be made by elected representatives, but affirm the positive role direct-democratic mechanisms can play in incentivising representatives to aim at constitutional decisions that all those subject to it can accept (Crum 2012). Either way, the subjects exercising constitutional agency always ought to be the member state's demoi.

One straightforward reason to find this strategy appealing is that locating constituent power in the demoi of EU member states seems to be descriptively accurate, inasmuch as member states are often said to remain the 'masters of the treaties' (Grimm 2016: 56-58); so from the point of view of realism, the first account has much going for it. Yet, as several commentators have pointed out, the focus on domestic pouvoirs constituants faces sizable obstacles. If constituent power refers here, as it typically does, to the more or less unrestrained competence to establish and revise constitutional orders, does this mean that member states' constituent powers also operate in an unbound fashion when they engage constitutional politics at the EU level? And if that is the case, what happens when conflicts between multiple pouvoirs constituants arise?

The first account of constituent power in the EU has no answers to these questions. Its assumption that the constituent power of the member states' peoples simply extends beyond the state, as if 'the involvement in EU 
constitutional politics represented just another mode of intra-state constitutional revision' (Patberg 2017: 206), indeed veils these problems. At work seems here the contestable Schmittian assumption that the allocation of constituent power is an either-or question, such that any exercise of constituent power beyond the state is bound to nullify the constituent power at the state level (cf. Cohen 2012: ch. 2).

Aiming to overcome such a view, the second account of constituent power in the EU that has been proposed in the recent literature on the topic offers a possible way forward. The suggestion is to conceive constituent power in the EU as pouvoir constituant mixte, understood as a supra-state constituent power in which individuals participate in their dual capacity as members of the member states' demoi, on the one hand, and Union citizens, on the other.

One prominent author who has developed such a view is Jürgen Habermas (2011; 2017). In his more recent work on the topic, Habermas specifically imagines a complex European constituent assembly in which delegates, represented in their two 'personae,' deliberate over the constitutional features of the EU (Habermas 2017; cf. Habermas 2011: 68-70). The thought is that, in such an assembly, individuals are 'able to address the other side with the aim of striking a balance between their respective interests' (Habermas 2017: 174), and thus able to devise constitutional norms and rules that prevent potential conflicts between the member states' pouvoirs constituants, whilst ensuring that individuals' normative expectations vis-à-vis the EU are given adequate expression.

Importantly, Habermas' approach is not intended as a descriptive account of how supra-state constituent power can operate as a real social force. Instead, its purpose is to demonstrate to what extent certain elements of the current EU 
constitutional order can be justified from an 'idealised participants perspective,' and which require revision (Habermas 2011: 69). Habermas' strategy is to start from the presumption that the EU has already assumed a democratic character as a result of the Treaty of Lisbon, and then conduct a 'rational reconstruction' of the practice of law-making and implementation in the post-Lisbon Treaty EU. Analogous to his more generalised reconstructive approach, as developed in Between Facts and Norms (1994), this entails asking what hypothetical delegates to a European constituent assembly would decide in an idealised rational dialogue about the EU's constitutional foundations.

No doubt, the notion of pouvoir constituant mixte presents a significant advance in theorising about constitutional agency in the EU. It can powerfully overcome the problems noted in connection with the first account of constituent power in the EU. Yet, if one seeks an action-guiding model of EU constitutional politics, Habermas' account is the wrong place to look. For, since it conceives suprastate constituent power in purely hypothetical terms, as a post hoc justificatory device for existing institutional arrangements, it effectively accepts that constitutional norms can plausibly be articulated in isolation from procedures of political contestation - without the participation of those to whom these norms are supposed to apply.

On a strong reading, one might say that Habermas' perspective provides not so much a solution to the problem that the constitutionalisation of the EU polity has taken place in a largely apolitical fashion, but a justification for the apolitical process of constitutionalisation that has so often been lamented. Although Habermas is generally sympathetic to a 'more democratic' EU, he stops short of offering prescriptions concerning the politicisation of the EU constitutional order. 
That Habermas conceives EU constitutional politics in purely counter-factual terms also raises another problem. Even if his approach of 'rational reconstruction' could settle all questions to do with the constitution of the EU at a particular moment in time, constitutional norms must - at least to some extent - be adapted to an evolving historical context. In relegating citizens to passive recipients of norms, however, Habermas' account leaves little room for bringing shifting preferences regarding their political communities and forms of collective organisation to bear on decisions concerning constitutional design.

To better understand this worry, consider Habermas' interpretation of the domestic dimension of the pouvoir constituant mixte. This is almost exclusively conservationist, in the sense that Habermas imputes to the citizens of member states' demoi a strong and stable commitment to conserve the 'revolutionary constitutional achievements of the past' (e.g. Habermas 2011: 70; also see von Achenbach 2017: 196). Yet even if citizens are currently so inclined, they might at some point in the future wish to re-invent themselves as a political community, perhaps in a 'co-evolution with their other persona' (Niesen 2017: 190). An account of constituent power that allows for such shifts cannot however remain tied exclusively to philosophical reflection; citizens must be made active participants to constitution-shaping, being able to translate rearticulations of member state communities into constitutional arrangements.

Moving beyond a purely counterfactual perspective, a number of scholars have asked how Habermas' notion of pouvoir constituant mixte might inspire the exercise of constitutional agency in the real world. ${ }^{1}$ Niesen (2017: 190-191), for example, toys with the idea that the Habermasian approach might hold the

\footnotetext{
${ }^{1}$ On the usefulness and plausibility of such a move, see also Arato (2016: 70).
} 
potential to empower 'future subjects of constitutional reform,' by providing them with a 'new language in which to ground transformative European citizen engagement.' Similarly, Patberg (2017: 210) interprets Habermas' model as inviting reflection on how the pouvoir constituant mixte can be 'brought into the world via a conscious decision taken by the demoi of the member states.'

To be sure, up until this point this line of Habermasian scholarship has mainly produced a number of suggestive remarks about possible ways of connecting principles of constituent power to political practice (see esp. Patberg 2018); and for this reason, it is little able to offer a clear vision of how the practice of constituent power could look. Nonetheless, the shift of emphasis from the ideal to the phenomenological that is suggested by authors such as Niesen and Patberg is helpful for normative theorising on the politicisation of EU constitutional politics, as it alerts us to the importance of thinking hard about how normatively desirable forms of constituent power could look in reality.

The most urgent questions to be explored in greater detail have to do with concrete and feasible organisational models for supra-state constituent power in the EU, the ideational resources that can support and sustain the collective pursuit of supra-state constitution-making, and the channels from which the sociological legitimacy of such efforts - roughly, the extent to which exercises of constituent power in the EU are considered legitimate by European citizens - can be expected to flow. The latter is of special relevance for a theory of constituent power that aspires to be democratic in the less philosophical sense of allowing space for contestation and dynamic change. Indeed, the fact that there is a 'deep relationship' (Arato 2016: 131) between sociological legitimacy and a democratic understanding of constitutional change and revision follows 
directly from the earlier-elaborated commitment to transcending a purely counterfactual perspective on constituent power.

My burden in the remainder of the paper is to address these questions and articulate an empirically informed model of how supra-state constituent power may be exercised in the EU. To that end, I will explore a hitherto neglected form of supra-state constituent power that rests on transnational partisan networks, through which like-minded individuals from different political spheres coordinate with the aim of shaping the constitutional order of Europe.

\section{Transnational partisanship and constituent power}

Reflecting on the prior section's discussion, we may single out several desiderata that an account of constituent power in the EU must meet.

1) It must be a 'mixed' form of constituent power whose participants act both in their capacity as members of states and as members of a supranational polity;

2) it must allow for participation and contestation; and

3) the institutional properties of constituent power must be specified, in particular

a) a feasible model of organisation,

b) ideational foundations that help justify and sustain the collective pursuit of supra-state constituent power, and

c) sources of (sociological) legitimacy.

These desiderata relate both to the normative-substantive and what may be called the 'methodological' aspects of theories of constituent power. The normative-substantive desiderata (1-2) derive in part from the suggestions put 
forth by Habermas (concerning the superiority of mixed accounts of constituent power relative to unitary ones), and in part from the scholarship of Patberg and Niesen (and their emphasis on the importance of practices of participation and contestation). The methodological desiderata (3), on the other hand, demand approaching the subject matter from an angle that is quite different from that taken by all of these authors, paying particular attention to the practical questions of how a supra-state constituent power can be realised.

The reason for this methodological shift is simple. If the debate around constituent power in the EU is to fully move beyond a counterfactual perspective, headway must be made on precisely those 'applied' questions that existing accounts only loosely touch upon or eschew altogether. In short, a model of pouvoir constituant mixte that is capable of guiding political practice has to spell out in more details how real-world citizens could act as shapers of the EU's constitution.

To develop such a model, I follow a strategy of theory-building that is historically-oriented and reconstructive. Taking as point of departure past practices of constitution-making and -shaping in the EU, I ask if and how these practices can provide a blueprint for constituent power that 'future subjects of constitutional reform' could follow. The particular set of practices I concentrate on - transnational partisan coordination that enables and supports the effective exercise of supra-state constituent power - has received little attention in the normative literature on the EU. Yet, as we shall see, tracing the contours of these unfamiliar forms of political agency can illuminate how a supra-state pouvoir constituant mixte might be organised.

A paradigmatic case of the kind of transnational partisan coordination I am interested in, one with direct relevance to the EU, is the Christian Democratic 
transnationalism that burgeoned in the interwar years and following World War II. Although parties of Christian Democratic orientation are not primarily known for their cross-border activities, their mode of cross-border organisation reflects a unique form of coordinating joint political action beyond the state.

Central to their organisational strategy were transnational party networks: these provided arenas for deliberation over constitutional questions regarding the founding of a common European order, as well as sites in which joint political action was coordinated. Because of the dominance of Christian Democratic parties in the original member states of the European Coal and Steel Community (ECSC) and the European Economic Community (EEC), these networks turned out to play a crucial role in realising European Union, providing a powerful model for organising supra-state constituent power. $^{2}$

Let us look more closely at this form of political agency and explore whether it may satisfy the aforementioned desiderata.

\subsection{Organising constituent power: Partisan networks}

One of the defining features of the transnational partisan networks developed by Christian Democratic parties is that they were mainly structured around informal exchanges. Dialogue about shared commitments was a primary function of these exchanges: the purpose was to foster discussion between politically like-minded individuals from different national spheres. The topics addressed ranged from general reflections on the present state and possible

\footnotetext{
2 The following is indebted to the excellent historical accounts of Christian Democratic transnationalism in Kaiser (2007) and Papini (1997), as well as the comprehensive edited volumes by Gehlen and Kaiser (2004) and Buchanan and Conway (1996). A further major resource used here for the purposes of reconstructing the distinctive features of Christian Democratic transnational organisation is the Volume 4 of the Documents on the History of European Integration Series B (1990), edited by Lipgens and Loth.
} 
future of the jointly espoused political project, to more specific questions to do with connecting principles to practice (Gisch 1990; Kaiser 2007: esp. ch. 5). Here the more general nature of partisan practice makes itself visible: partisanship is not just about formulating political proposals, but also about implementing them (Rosenblum 2008; White and Ypi 2016).

Insofar as transnational partisan coordination of this kind is about implementing political aims, it can be harnessed to realise objectives that single states cannot achieve on their own - for example by helping national parties synchronise their actions and activities in a way that allows them to execute larger tasks. From the point of view of EU constitutional politics, this is one of the most attractive features of this form of cross-border organisation, and the reason for why it can facilitate the exercise of supra-state constituent power. There are two different, sequential roles that the Christian Democratic partisan networks performed in this connection - roles we may consider in turn.

The first is preparatory: transnational partisan networks can over time lay the groundwork for the future enactment of constituent power beyond the state, helping individuals to overcome difficult challenges associated with exercising power trans- or supranationally. Chief amongst these challenges is a lack of agreement among members of the network as to the goals to be pursued in concert. Likewise, the national parties that form the network may simply lack the means to directly translate their shared aims into decisions, for instance because they are not in government in their respective states. Transnational party networks can contribute to solving these problems, in that they provide platforms for cross-national dialogue aimed at devising common strategies to gain power in the future and/or developing a shared vision that all national parties uphold. 
To see what this means in practice, consider one transnational party network that may straightforwardly be interpreted as having prepared later exercises of constituent power - the Secrétariat International des Partis Démocratiques d'Inspiration Chrétienne (SIPDIC). SIPDIC was a transnational organisation of Catholic parties that was founded in 1926 by the Italian left-wing Catholic Luigi Sturzo with the primary aim of fostering lasting peace between the peoples of Europe. The organisation disintegrated in 1939, in part because many democratically-minded Christian parties were put under severe pressure by fascist regimes, but also because the involved parties were unable to agree on a shared agenda of political objectives (Kaiser 2007: 116). Yet, although SIPDIC failed as a transnational organisation, the cross-border exchanges that occurred under its aegis proved crucially important for the Christian Democrat's constitution-shaping activities after World War II.

There are three senses in which this is true. Firstly, as historians of Christian Democracy (ibid.: 117) have pointed out, the transnational dialogue SIPDIC facilitated helped overcome a general reluctance among Christian Democratic parties to organise transnationally - a reluctance rooted in the view that the Catholic Church is the only legitimate international representation of Catholic interests and ideas. This was an important precondition for effective transnational organisation after the War.

Secondly, the deliberations among SIPDIC's members also promoted a collective learning process, showing 'to all involved that party cooperation could only be effective if it combined strictly pro-democratic parties with a shared value system and was extended to democratic liberal and conservative Catholics to broaden its basis and strengthen its potential influence - and that it required some shared core strategic policy objectives' (ibid.). Though this 
learning process did not result in programmatic agreement in the interwar years, as I have noted, it prepared the post-war emergence of an ideological consensus among Christian Democrats concerning European unification (see below).

Thirdly, though there was no direct organisational continuity between the networks formed around SIPDIC and the transnational associations that formed after World War II, key figures of post-war Christian Democracy notably Konrad Adenauer and Robert Schuman - attended SIPDIC meetings and congresses and engaged in the association's deliberations about the unification of Europe. It is not implausible to assume that their participation at these events shaped their views on achieving European unification, facilitating future agreement about collective goals - though it was only the mutual exchanges in the later-founded Nouvelles Équipes Internationales (NEI) that 'created the basis of personal confidence among ... such politicians as Schuman, De Gasperi and Adenauer, which ... made possible the policy associated with their names' (Gisch 1990: 484).

Importantly, as a practice of reasoning that involves individuals who are both members of nation states and potential members of a future supranational European order, the just-mentioned deliberations within SIPDIC may be interpreted as instantiating the sort of 'two-personae' exchanges envisaged in the Habermasian conception of pouvoir constituant mixte. In a sense, one may say that the success of SIPDIC was undermined by the fact that the interests tied to the first 'persona' - being a member of a particular nation state - were of greater significance to many of the participants than the interests associated with the (hypothetical) second persona. The French Popular Democrats, for one, mainly sought to use SIPDIC's network to foster alliances against revisions 
of the Versailles Treaty and, thus, also against the German Centre Party and Germany more generally. This created an atmosphere of mistrust among the parties and triggered numerous debates that were primarily about the assertion of national interests, rather than about goals shared by all network members. This was to change in the post-war era, where, as we shall see, Christian Democratic partisans were better able to bring their national commitments and trans- or supranational visions into equilibrium.

I now turn to the second role transnational partisan networks can serve, which is even more relevant to the question of constituent power than the first. This may be called their executive role and refers to instances where members of partisan networks are capable of putting their shared goals into effect. At least two conditions must be met in order for this to be possible. The first is that members of the network agree on the aims and goals they wish to pursue in concert. Why this is crucial is not difficult to see: disagreement over possible courses of action often has action-impeding implications, sometimes even erodes mutual trust amongst those who associate with the purpose of acting together. The example of SIPDIC shows that transnational partisan networks are not immune to these problems.

The second condition may likewise be inferred from the above discussion: this is that most or all of the parties forming the network are in a position that permits them to exert significant influence on general norms and laws, for example that they are in government in their respective states. Again, it is easy to see why this is important. If transnationally shared aims concerning the founding or constitutional revision of a supra-state order are to be realised, individual members of the partisan networks must also be capable to authoritatively shape (national) laws and constitutions. Holding office may further be seen as 
warranting the (sociological) legitimacy of constituent agency: weighty ambitions of the kind typically involved in enactments of constituent power arguably require public support, and having gained sufficient electoral strength to be in government may plausibly be interpreted as signalling that such support is available.

When these two conditions - agreeing on shared goals and having access to power - are satisfied, transnational partisan networks can provide a springboard for the co-operative implementation of shared projects across nation states. What does that involve exactly? One important thing transnational partisan coordination can ensure in this connection is that certain key decisions are taken more or less simultaneously in each state: for instance that all members of a future or present supranational community enact a major constitutional change at roughly the same time, or agree to the core constitutional features of a new, supra-state political order.

The cross-border exchanges enabled by partisan networks may likewise facilitate coordinating strategic reactions to temporary political failures or crises, as well as to national and transnational dissent and resistance facing partisans. Reactive actions of this sort are instrumental to the realisation of trans- or supranational political projects, and they squarely fall in the category of executive action since they involve jointly taking authoritative steps aimed at keeping on track the implementation of a shared political project.

The Christian Democrats' transnational partisan networks were able to exercise this executive function mainly in the period after 1950, when Christian Democratic parties were the dominant political force in all six member states of the ECSC and EEC. Being connected to the relevant legislative and executive mechanisms in these states, the national parties were capable of realising 
politically their shared supra-state project of building the constitutional foundation of 'core Europe' - and their transnational network was a major enabling factor in these exercises of constituent power.

The first thing to note is that transnational party cooperation, notably via the consultations and congresses that took place in the newly-established NEI and the more informal Geneva Circle, promoted the homogenisation of policy objectives among Christian Democrats and more generally allowed them 'to develop their own peculiar notion of "Europe"' (Gehler and Kaiser 2001: 780).3 The ideological consensus that emerged - most emphatically perhaps at the Sorrento congress in April 1950 - was not only a distinctively anti-communist but also, to some extent at least, an anti-liberal one: it not only opposed the areligious materialism of Stalin's Russia, but also linked the horrors of the two World Wars to the ostensibly liberal roots of modern nationalism (Gisch 1990: 480-484; Acanfora 2015). ${ }^{4}$ At any rate, these shared ideological commitments also led Christian Democrats to converge on preferences concerning European integration - a convergence that, as one historian notes, was a 'precondition for

\footnotetext{
${ }^{3}$ The necessity of agreeing on shared goals was widely recognised by Christian Democratic actors, as is evidenced in many recorded passages and communiqués. To cite just one example, the NEI's official message of 1 January 1949, which it addressed to the European public, stresses at the outset that 'One cannot establish a European union ... without agreement on a common ideology' (Message NEI 1949, ACDP Archives, NEI no. VI-004-002 or 004-059/3).

${ }^{4}$ The 'political report' of that congress, which was attended by leading statesmen from 15 European countries, is insightful here. It starts by emphasising that 'Christian Democratic movements have acquired a predominant position in postwar European political life. They have a double mission that no other political force is capable of fulfilling: (a) To improve the lot of workers ... (b) To create a solid international community, or rather a supranational one. These two aims must, or rather can, be achieved only by democratic means.' Later, it is stated that 'The Christian Democratic movements are by their nature anti-totalitarian ... we fight Communism because it bars the way to the creating of a Christian society' and that 'If by liberalism is meant the economic regime of complete laisser-aller, to that extent Christian Democracy is anti-liberal' (NEI, Congrès de Sorrente, ACDP Archives, NEI no. VI-004-011/4).
} 
developing common ideas for the constitutionalisation of core Europe and for preparing concrete European policy-making' (Kaiser 2007: 240).

The transnational deliberations that paved the way for this ideological convergence, insofar as they have been documented, may again be interpreted as reflecting the sort of 'two personae' logic that the exercise of mixed constituent power demands. A highly structured way of preparing transnational exchanges made this possible. For example, prior to the NEI's 1954 Bruges congress, which culminated in the passing of the 'Manifesto of Bruges,' which outlined the Christian-Democratic project of a European common market, the Belgian Christian Social politician Robert Houben, in his capacity as rapporteur for the Bruges congress, developed a detailed questionnaire on issues of European economic integration that he sent out to each national branch of the Équipes (Gehler and Kaiser 2001: 792). The answers national party representatives provided - qua citizens of European nation states - in turn served as the basis for deliberations at the congress, where participants also addressed each other qua members of a future European political order that transcends individual nation states.

How did transnationally organised Christian Democrats eventually bring their shared vision of Europe to bear on constitutional decisions, enacting constituent power? It is important to note that the influence of transnational party networks remained mainly indirect: though they undoubtedly 'saw it as their role to influence the process of integration in the direction of their own philosophy and programme' (Gisch 1990: 481), Christian Democrats never intervened directly via the NEI or the Geneva Circle in the negotiation and implementation of economic treaty clauses. Neither in connection with the ECSC treaty, nor in connection with the EEC treaty, did transnational party 
networks exercise power in an unmediated fashion (Kaiser 2007: 222). But this does not mean that their influence was negligible. The opposite is the case. For this was a period where, as we saw, national governments and ministries were largely controlled by Christian Democrats, and so the transnationally agreed political commitments made their way into the intergovernmental negotiations without the need for direct political interference of party networks. Not least because key Christian Democratic figures on the top of their respective party hierarchies (such as Konrad Adenauer) were at the forefront of transnational coordination, the transnationally agreed objectives could powerfully be channelled into intergovernmental decisions. It is not difficult to interpret this as exemplifying the political pragmatism that is a more general characteristic of Christian Democratic political strategies (cf. Kalyvas and van Kersbergen 2010): there was simply no need to intervene in a process that was in any case largely controlled by partisans of Christian Democratic persuasion.

With all that in mind, we may turn now to the question of whether the justdiscussed model of transnational organisation aimed at exercising supra-state constituent power satisfies the desiderata specified at the outset of this section. How does the transnational partisan account of constituent power fare in this respect?

So far, it seems clear that it can satisfy desideratum (1), that which emphasises that the supra-state constituent power in Europe ought to be a 'mixed' form of constituent power, whose participants act both in their capacity as members of states and as members of a (present or future) supranational polity. The crossborder communication enabled by transnational partisan networks can indeed induce dialogue between the two Habermasian 'personae.' There furthermore appears to be good reason to think that constituent power exercised via 
transnational partisan networks is in principle a feasible organisational model (thus satisfying desideratum 3a). It may be considered feasible not only because it has been powerfully demonstrated to be workable provided that the requisite political will is available. Also, and perhaps more importantly, since it obtains its norm-creating power and legitimisation at the member state level it does not demand a complex supra-national institutional structure to operate effectively. This leads to a third point: in relying on electoral support in national political arenas, the model also specifies from which channels its sociological legitimacy can be expected to flow (thus satisfying desideratum 3c).

\subsection{Justifying and sustaining constituent power: The role of ideology}

Two of the above-stipulated desiderata have not been addressed yet. These are desideratum (2) - which demands that an action-guiding model of constituent power must allow for participation and contestation - and desideratum (3b) which highlights that such a model will have to be underpinned by ideational foundations that help justify and sustain the collective pursuit of supra-state constituent power. I will take these in reverse order, speaking first to (3b). Before doing so, however, a more fundamental question needs handling. Why does it matter exactly that supra-state constituent power can rely on ideational foundations that support its justification and coordinated pursuit?

As far as justification is concerned, one might say that, insofar as supra-state constituent power is not exercised directly by citizens but indirectly via elected representatives, as it is the case in the model the present paper concentrates on, it can claim to be exercised in a democratic fashion only if as its exercise can be justified to citizens (cf. Böckenförde 2006: 103). For justifications to be accepted, though, the reasons given for particular constitutional decisions - for example concerning the shape a future supranational order will take - must be rendered 
meaningful and intelligible to citizens. Here it helps a great deal to be able to draw on ideational foundations - ideas, values, and rhetorical figures - that have resonance with a wider public because they form part of political ideologies that are deeply rooted in the relevant societies (cf. White and Ypi 2016: ch. 3). ${ }^{5}$

As far as support for the continual exercise of constituent power is concerned, a common ideational substrate is important because it can motivate those who aim at enacting constituent power (and others) to want the intended constitutional change to happen, encouraging them to put special efforts and energies into realising their ambitions over extended time. Theorists of parties sometimes speak in this connection of the 'motivational benefits of partisanship,' understood as the capacity of ideological commitments to help agents endure motivational and epistemic obstacles to the achievement of their political project (White and Ypi 2016: 85-96). Such resilience is indispensable when major acts of constitutional transformation are aimed at.

A model of constituent power that centres on partisanship appears naturally well-suited to offer something in the way of ideational resources that facilitate the justification and sustained collective pursuit of constitutional founding or reform. For partisanship may be seen as a powerful underpinning not just to the sort of political commitment that reinforces the motivation of agents to act as constituent power, but also to the kind of justificatory activity necessary to endow the exercise of constituent power with democratic legitimacy (Rosenblum 2008; White and Ypi 2016). Ideology is not something to look to with scepticism when it comes to constituent power, in other words; rather, it

\footnotetext{
${ }^{5}$ Note that in justifying the exercise of constituent power, a contribution is also made to the sociological legitimacy of the undertaking, as specified by desideratum (3c).
} 
should be regarded as providing socially rooted normative ideas that can be harnessed for the successful enactment of the latter (cf. Kalyvas 2006).

A minimum requirement that must be met in order for an ideology to provide a suitable ideational underpinning for supra-state constituent power is that it can be reframed in transnational terms, as transcending particular geographical settings rather than reflecting the viewpoint of specific local constituencies (White and Ypi 2016: 202-203). ${ }^{6}$ Moreover, when it comes to supra-state constituent power in the EU, presumably the simple fact that a political ideology can be presented in transnational terms is not sufficient for it to serve the aforementioned supporting roles; it must also be linked to diagnostic and prescriptive claims about Europe in particular, the geographical setting whose transformation is the ultimate intention. This involves clarifying vis-à-vis citizens how re-shaping the political constitution of Europe follows from specific transnational political commitments. Equally, it entails drawing, at least provisionally, lines of demarcation, delimiting where Europe begins and where it ends, and giving reasons for why the proposed boundaries are plausible. Without 'localising' transnational ideologies in this way, it is certainly difficult to imagine how the constitutional transformation of Europe could be justified to citizens.

A glance at the Christian Democratic model of supra-state constituent power outlined here helps to better understand what it means to 'transnationalise' a

\footnotetext{
${ }^{6}$ Arguably this will not work for all ideologies, especially not those that define themselves against their neighbours. But as the history of transnational nationalism demonstrates, even political orientations that one would instinctively expect to resist 'transnationalisation' can be cast as aspiring to be a transnational community of commitments (Herren 2017; Zúquete 2015).
} 
political ideology, to 'localise' that ideology in the context of Europe, as well as to employ it as a justificatory resource.

Above I have already noted that an ideological consensus emerged among Christian Democrats in the post-war era, one that had not only anti-communist but also anti-liberal pretensions. This consensus was structured around views that go back to the advent of Christian Democracy as a political movement, most importantly the doctrine of 'personalism,' which sees the human being as constantly embedded in groups and natural communities that are not necessarily coextensive with the nation state (hence the opposition to the species of political liberalism that centres on powerful secular and centralised nation states), and the notion that Europe is a spiritual realm at the origin of which Christianity lies (hence the opposition to the materialist world view that characterises communism and, to some extent at least, also liberalism) (Forlenza 2017: 268-269; Kaiser 2007: 228-229). It is easy to see how these ideas could ground a transnational vision for a unified Europe that is, at the same time, still 'local' enough to appeal to shared historical understandings of what Europe is (Kalyvas and van Kersbergen 2010: 196).

In fact, much as the twin ideas of personalism and Europe as a distinctively Christian realm supported the project of establishing a unified Europe with shared trans- or supranational political institutions, they also opened the door to very narrow conceptions of where the boundaries of Europe lie. ${ }^{7}$ In particular, the notion of Europe as a spiritual space that is, at bottom, a

\footnotetext{
${ }^{7}$ To get a flavour of the language used, consider the 1948 statement of the NEI's Cultural Commission on 'Europe as a Cultural Unit': 'The European spirit, which has always striven for unity and can never exist in a diaspora, has been and is the conscience of mankind. ... [and] [t] he unifying life-force of Europe has always been Christianity' (ACDP Archives, NEI no. VI004-101(4)).
} 
Christian civilizational project often went hand in hand with idealisations of the pre-modern and pre-national Catholic West or Abendland. From this, it is only a short step to the kind of anti-Protestantism that conceives the boundaries of Europe as congruent with the Catholic countries of Western Europe, not to mention the tendency to assert the primacy of Catholicism over non-Christian religions (cf. Rosenboim 2017: 252-257). Even among the EU's 'founding fathers' positions of this sort were not uncommon (Forlenza 2017: 272-273).

Be that as it may - I shall return to these more problematic features of Christian Democratic ideology in the concluding section - what cannot be denied is that the Christian Democratic rationale for an integrated Europe was ultimately a powerful one, and one that resonated sufficiently with mass audiences to serve the purposes of political justification. It is of course true that Christian Democratic politicians, even if they held this view, rarely publicly presented their plans of an integrated Europe in terms of creating a democratic Carolingian Empire that restores the natural order of European history. Nonetheless, the idea of Europe 'as an ideal and moral fatherland understood in no way as in opposition to, but rather as a natural development of, the traditional [national] fatherland' was a recurring trope in the political rhetoric (and writing) of key Christian Democratic figures (Forlenza 2017: 276 and 279). This trope could be usefully employed to justify the integration of nation states into a larger supranational order that required delegating sovereignty to new European bodies, at a time when historicised religious or quasi-religious arguments still had traction with mass publics.

The distinctive political ideas that undergird transnational Christian Democracy are complex, and so are the ways in which they have been put to use. The main point to note is that Christian Democratic ideology provided a 
potent ideational foundation for the exercise of constituent power aimed at creating a united Europe after World War II; the fact that 'the core ideological concepts of Christian democratic politics seemed ready-made for European integration' (Kalyvas and van Kersbergen 2010: 196) considerably facilitated the coordinated enactment and justification of the major constitutional changes the members of the transnational network of Christian Democrats intended. No doubt, then, desideratum (3b) is also satisfied by the Christian Democratic model of supra-state constituent power.

\subsection{Constituent power without participation?}

This leaves us with desideratum (2), which plays up the importance of popular participation and contestation. As discussed in the paper's first section, a primary normative requirement that must be met by accounts of supra-state constituent power in the EU is that they include citizens more directly in the exercise of constituent power; citizens ought to be given the opportunity to participate actively in constitution-making activities and be able to contest past constitutional arrangements on their own terms. Can the proposed strategy of grounding constituent power in transnational partisanship deliver on this concern?

One way of looking at the practice of transnational partisanship is to see it as almost inevitably elitist. Accordingly, it may well be that its component parts national and local parties - are participative, but the transnationally pursued coordination will tend to remain driven by political elites who possess the requisite cross-border contacts (as well as the linguistic abilities to communicate with their counterparts from other countries). If true, this would signal reason for the utmost pessimism concerning the capacity of the transnational partisanship-facilitated model of supra-state constituent power 
to satisfy desideratum (2). The unavoidably elite-centred nature of transnational partisanship precludes inclusive participation and contestation.

The assumption that elitism is intrinsic to transnational partisanship certainly finds confirmation in the Christian Democratic transnationalism this paper engages with. While the history of Christian Democracy may plausibly be interpreted as characterised by a gradual, if sometimes reluctant, espousal of mass democracy (Kaiser 2007; cf. Müller 2011: 141-143), there is a very clear sense in which many of the key figures behind the constitutionalisation of core Europe 'espoused a top-down culture of public administration in which decision making was largely remote from the people,' and 'believed in supranationalism as something done by well-connected elites of high-minded planners and bureaucrats' (Forlenza 2017: 278-279). It is easy to see the secretive and elitist structure of the transnational associations we have encountered earlier - the NEI and the Geneva Circle - as giving institutional expression to this attitude. Citizens are thereby relegated to the status of passive recipients of constitutional choices, who, despite retaining the capacity to vote the parties who collaboratively exercise constituent power out of office, have close to zero influence on the decisions of elites.

Should we infer from this that the Christian Democratic model of supra-state constituent power fails to satisfy desideratum (2), and hence that the model is inadequate as a blueprint for constituent power in the EU? A modest qualification of this view would highlight that, even if citizens were largely excluded from participation, the parties whose elites associated transnationally with the aim of shaping Europe's constitutional order still enjoyed widespread electoral support domestically, in the six original member states of the ECSC 
and EEC. The acquiescence of mass publics would at least seem to weaken the concern that a failure to satisfy desideratum (2) disallows the model as a whole.

One might be tempted to go one step further and draw a normative conclusion from this observation: namely that desideratum (2) should generally be framed more loosely, being accommodated to circumstances where discretionary decision-making by political elites is widely considered legitimate by citizens. The intuition is that, while it cannot be denied that participation matters, it would be implausible to assert its ultimate importance in cases where constituent power is endowed with what I have called sociological legitimacy (3c). Is the way forward then to think of the satisfaction of desideratum (2) as in-principle desirable but not necessary? If so, we would have to say that there is nothing problematic about the elitist character of the Christian Democratic model of constituent power.

But such a position would be spurious. It is possible to accept that broad popular participation in acts of constituent power can be less important in some moments than in others, while retaining the view that a model of constituent power that lacks participatory channels altogether is insufficient. A loosening of desideratum (2) cannot go so far as to lead one to affirm the primacy of elitedriven over bottom-up and participatory constitution-making. This would be normatively objectionable if the arguments about constituent power that I have examined at the outset of the paper are sound, according too negligible a role to citizens in the shaping of the fundamental institutions of their political order. In this light, it would seem that there are still good reasons to think that the way in which Christian Democrats have organised supra-state constituent power leaves much to be desired. This despite the fact that their transnational 
mode of coordination has many other attractive features possibly worth emulating.

\section{Revisions to the Christian Democratic model}

These initial reflections on the shortcomings of the Christian Democratic model of 'networked' constituent power instructively reveal that some revisions to the model are required if it is to be normatively defensible and capable of providing a point of orientation for supra-state constituent power in the EU today. While the model has many attractive features, and has been demonstrated to be in principle feasible, it cannot be adopted without modifications.

In these final paragraphs, I want to suggest three necessary amendments. The first has already been evinced in the prior section: in contrast to the elitism of Christian Democrats, contemporary efforts to harness transnational partisan networks for the exercise of constituent power beyond the state ought to involve citizens in a participative fashion.

The normative argument for conceiving constituent power in participative terms has already been rehearsed. The main concern, to repeat, is that constitutional acts cannot plausibly be said to be the product of a decision by 'the people' if the latter are merely the recipients of decisions that are made without their involvement. Another question is the practical one of how transnational partisan networks could be designed in a sufficiently participatory and inclusive fashion. There are no doubt serious obstacles in the way. Chief amongst these is the challenge of scope: it is difficult enough for a small number of political elites to effectively coordinate across borders; these 
difficulties are multiplied when larger numbers of citizens are involved, especially if most or all of them are supposed to have a say on decisions.

How could these hurdles be overcome? What is certain is that some democratic division of labour is unavoidable. Even the most inclusive and participatory model of transnational partisan coordination we may be able to imagine cannot continually include all of its members in its decision procedures. Too geographically dispersed are the individuals involved to ensure that all of them have a seat at the table; too many potential voices will exist there to be convened in the same forum; and if ordinary citizens are to be implicated in the process, most probably their time constraints will also constrain their participation. Yet even if mechanisms of delegation or representation will necessarily be part of transnational partisanship, there are still diverse ways of including citizens.

One would be to place the emphasis on national 'nodes' of the partisan network as sites of popular participation, and link these nodes together in a democratic fashion. The local chapters of the participant parties could accordingly provide venues in which citizens engage in deliberations about the larger constitutional project they seek to realise and select representatives who stand up for them in those transnational fora where decisions are taken (Wolkenstein 2016: 316). The organisational model adopted by the emerging transnational party DiEM25 may be interpreted along these lines: its aim is to connect the views and ideas of local activists and supporters to the transnational level via democratic representatives, relying both on participatory forms of party membership and intra-party accountability. Whether this model is sustainable in practice remains to be seen, of course. But on its face, it seems capable of overcoming the challenge of scope I have highlighted. 
The second modification I propose is relevantly related to the first but cannot be assimilated to it. This is that, contrary to Christian Democratic practice, future transnational partisan projects that seek to shape the EU's constitution must be ready to submit actions to public approval.

As we have seen earlier, many Christian Democratic partisans who were engaged in the transnational project of constitutionalising core Europe tended to be sceptical of mass politics. If one consequence of this was that their transnational groups remained highly exclusive (think of the Geneva Circles), another was that they refused to submit their constitutional decisions to public approval. Relying on the acquiescence of mass publics, they rather proceeded in a mode described by one commentator as 'emergency regime, with regular steps of constitutional significance taken by executive decision, legitimacy sought in securitising narratives, and dissent discredited as resurgent nationalism' (White 2016: 312). Political justification was intermittently offered, but popular authorisation was rarely directly sought.

Transnationally enacted constituent power, it seems, will have to be careful not to regress to a form of 'emergency politics' if it is to be democratically defensible. While it is true that moments of constitutional change are exceptional moments where politics departs, to some extent at least, from the constraints of existing political and legal frameworks, agents of exceptional action can only plausibly claim that their decisions were democratic when they obtained approval from a wider public. One straightforward way in which this may be achieved is by inviting the participation of citizens, as illustrated a few paragraphs earlier. But there are also other ways in which public approval might be secured. 
Calling elections in the immediate aftermath of constitutional change is one possibility, but it is arguably strategically unwise if the aim is to realise an ambitious project of constitutional change. After all, since the capacity of transnational partisan networks to put their constitutional-political aims into effect depends on the electoral support their component parties have achieved nationally, early elections at potentially polarised junctures jeopardise the longterm feasibility of the constitutional project as a whole. An equally risky alternative is the referendum, which likewise may destabilise partisan networks and eventually impair their ability to act as agents of constitutional change. Yet it is also possible to imagine institutional devices that are less prone to induce uncertainty, and perhaps even better suited for constitutional politics. The kind of constitutional 'crowdsourcing' that has been tried out in Iceland would seem to provide a model that avoids the just-discussed pitfalls of more 'plebiscitary' forms of seeking public approval (Landemore 2015).

Finally, the third necessary revision to the Christian Democratic model has to do with the ideational foundations of Christian Democracy. If the distinctively Catholic (and, as we saw, anti-liberal and anti-communist) vision for an integrated Europe proved powerful and persuasive in the immediate post-war years, today and in the future a genuinely European political project must offer a more inclusive justificatory rationale for constitutional change.

An initial worry concerning this suggestion is that it smuggles substantive normative commitments into the theory of constituent power and thereby preempts the judgments of citizens as to what sort of constitution they prefer and what reasons they provide in support of it - a criticism analogous to that which I have levelled at accounts of constituent power that leave no space for citizen participation. But this is not my intention. My point is not that the Christian 
Democratic idea of Europe as discussed above is objectionable from the point of view of justice - though the case for this view could easily be made - but that it is arguably out of sync with the realities of contemporary Europe and hence impotent as an ideational underpinning for constituent power. The concern is pragmatic, not moral, in substance: widespread mobilisation and effective justification will be difficult to achieve with a specifically Catholic story of Europe unity.

That this might be the case has certainly been sensed by many Christian Democratic parties in the last two decades or so. As two observers note, many have 'completely erased any reference, even perfunctory, to religion' in their political agendas (Kalyvas and van Kersbergen 2010: 203), which has also informed their defence of an integrated Europe. Key Christian Democratic politicians today rarely invoke ideas of a spiritual 'community of fate' when they speak of the EU; the dominant diction is rather one that asserts the lack of alternatives to EU integration (White 2016; Seville 2017). The task for future transnational partisan projects aimed at constitutional change is to develop an ideational substrate that is capable of challenging this understanding of Europe without relapsing into an analogous emergency rhetoric or an excessively narrow conception of Europe's boundaries. Current attempts to present constitutional change as the only means to secure the EU's survival - the strategy of DiEM25 (Redder 2017) - would seem to fall short of these requirements. Even if effective on a short timescale, such moves risk excluding those who are uncertain as to whether survival is a goal worth pursuing in the first place, and may justify circumventing public approval when critical decisions are made. To be sustainable, transnational partisan projects must employ a broader, and more long-term vision of Europe. 


\section{Conclusion}

Recent times have seen a spirited debate on constitutional politics in the EU, with many scholars and activists problematizing that the constitutional order of Europe is insufficiently politicised. The guiding thought is that the EU can only claim to be genuinely democratic if its citizens can be considered the source of its constitution, and the subjects with whom sovereignty ultimately rests - which implies that constitutionalisation must not be driven solely by courts or political elites that act in isolation from practices of political contestation. The forward-looking task, then, is to reflect on ways in which EU citizens could be transformed into a constituent power, ideally one that operates above the level individual member states.

The present paper has outlined a particular institutional model for supra-state constituent power that highlights how the normative principles of 'mixed' constituent power could be linked to political practice. It looked for inspiration to the transnational networks of Christian Democratic partisans that played a central role in the emergence of the European Community in the post-war era, examining the distinctive features of this model of supra-state constituent power. If the Christian Democratic model has several shortcomings that require modification, it also exhibits numerous attractive features future agents of EU constitutional reform could usefully draw on. It is not a one-size-fits-all foil that can directly be translated into political organisation; nor does it provide an undemanding way of organising constitutional agency, requiring as it does that political power can effectively be wielded by the parties to the transnational network. But it does signal that they are in-principle feasible modes of organising constituent power beyond the state that can be democratically legitimate. And if DiEM25's current efforts to create a transnational party are 
any indication, it seems plausible to conclude that transnational partisanship is not an idea of the past, either.

To some readers, the suggested model of EU constitutional politics might seem excessively demanding. For not only requires it of those who seek to democratically re-invent the EU to organise transnationally, it requires them to mobilise and win elections in multiple, possibly even a majority, of EU countries. Arguably this sets the bar very high, and makes bottom-up constitutional change driven by transnational partisanship look like an unlikely prospect. But it is open to question whether constitutional reform initiated through transnational partisan coordination must take the exact same shape today that it did in the founding years of what eventually became the EU, that is, having parties of the same stripe form government in all member countries. It is at least imaginable that, once a critical mass of citizens supports the idea of constitutional change, governing parties that were not initially in favour of that idea become willing to cooperate in transnational constitutional politics. And of course, one might also reasonably ask whether there is anything wrong with models of constitutional change being demanding. That constitutional change should be easy is not a notion commonly entertained at the level of nationstates, and there is little reason to think that we should revise that intuition when it comes to exercises of supra-state constituent power. 


\section{References}

Acanfora, P. (2015) 'Christian Democratic Internationalism: The Nouvelles Equipes Internationales and the Geneva Circles between European Unification and Religious Identity, 1947-1954.' Contemporary European History 24(3), pp. 375391.

Arato, A. (2016) Post-Sovereign Constitution Making: Learning and Legitimacy. Oxford: Oxford University Press.

Bickerton, C. (2012) European Integration: From Nation States to Member States. Oxford: Oxford University Press.

Böckenförde, E. (2006) `Die verfassungsgebende Gewalt des Volkes - Ein Grenzbegriff des Verfassungsrechts.' In E. Böckenförde and D. Gosewinkel (eds.) Wissenschaft, Politik, Verfassungsgericht: Aufsätze von Ernst-Wolfgang Böckenförde. Frankfurt am Main: Suhrkamp, pp. 97-119.

Buchanan, T. and M. Conway (1996) (eds.) Political Catholicism in Europe 1918-1965. Oxford: Clarendon Press.

Cheneval, F. (2011) The Government of the Peoples: On the Idea and Principles of Multilateral Democracy. New York, NY: Palgrave Macmillan.

Cheneval, F., S. Lavenex and F. Schimmelfennig. (2015) 'Demoi-cracy in the European Union: Principles, Institutions, Policies.' Journal of European Public Policy 22 (1), pp. 1-18.

Cohen, J.L. (2012) Globalization and Sovereignty: Rethinking Legality, Legitimacy, and Constitutionalism. Cambridge: Cambridge University Press.

Crum, B. (2012) Learning from the EU Constitutional Treaty: Democratic Constitutionalization beyond the Nation-State. New York, NY: Routledge.

Fabbrini, S. (2016) 'The Constitutional Conundrum of the European Union.' Journal of European Public Policy 23 (1), pp. 84-100.

Forlenza, R. (2017) 'The Politics of the Abendland: Christian Democracy and the Idea of Europe after the Second World War.' Contemporary European History 26 (2), pp. 261-286.

Gehler, M. and W. Kaiser (2004) (eds.) Christian Democracy in Europe since 1945. London: Routledge.

Gehler, M. and W. Kaiser (2001) 'Transnationalism and Early European Integration: The Nouvelles Equipes Internationales and the Geneva Circle 1947-1957.' The Historical Journal 44 (3), pp. 773-798. 
Gisch, H. (1990) 'The "Nouvelles Équipes Internationales" (NEI) of the Christian Democrats.' In W. Lipgens, and W. Loth (eds.) Documents on the History of European Integration, Volume 4: Transnational Organizations of Political Parties and Pressure Groups in the Struggle for European Union, 1945-1950. Florence: European University Institute, pp. 477-484.

Glencross, A. (2014) 'The Absence of Political Constitutionalism in the EU: Three Models for Enhancing Constitutional Agency.' Journal of European Public Policy 21 (8), pp. 1163-1180.

Grimm, D. (2015) 'The Democratic Costs of Constitutionalisation: The European Case.' European Law Journal 21 (4), pp. 460-473.

Grimm, D. (2016) Europa ja - aber welches? München: C.H. Beck.

Habermas, J. (1994) Faktizität und Geltung. Frankfurt am Main: Suhrkamp.

Habermas, J. (2011) Zur Verfassung Europas: Ein Essay. Frankfurt am Main: Suhrkamp.

Habermas, J. (2017) 'Citizen and State Equality in a Supranational Political Community: Degressive Proportionality and the Pouvoir Constituant Mixte.' Journal of Common Market Studies 55 (2), pp. 171-182.

Herren, M. (2017) 'Fascist Internationalism.' In G. Sluga and P. Clavin (eds.) Internationalisms: A Twentieth-Century History. Cambridge: Cambridge University Press, pp. 191-212.

Kaiser, W. (2007) Christian Democracy and the Origins of European Union. Cambridge: Cambridge University Press.

Kalyvas, A. (2005) 'Popular Sovereignty, Democracy, and the Constituent Power.' Constellations 12 (2), pp. 223-244.

Kalyvas, S. N. and K. van Kersbergen (2010) 'Christian Democracy.' Annual Review of Political Science 13, pp. 183-209.

Landemore, H. (2015) 'Inclusive Constitution-Making: The Icelandic Experiment.' Journal of Political Philosophy 23 (2), pp. 166-191.

Lipgens, W. and W. Loth (1990) (eds.) Documents on the History of European Integration, Volume 4: Transnational Organizations of Political Parties and Pressure Groups in the Struggle for European Union, 1945-1950. Florence: European University Institute.

Loughlin, M. (2014) 'The Concept of Constituent Power.' European Journal of Political Theory 13 (2), pp. 218-237. 
Müller, J. (2011) Contesting Democracy: Political Ideas in Twentieth-Century Europe. New Haven, CT: Yale University Press.

Niesen, P. (2017) 'The 'Mixed' Constituent Legitimacy of the European Federation.' Journal of Common Market Studies 55 (2), pp. 183-192.

Papini, R. (1997) The Christian Democrat International. Lanham, MD: Rowman \& Littlefield.

Patberg, M. (2017) 'The Levelling Up of Constituent Power in the European Union.' Journal of Common Market Studies 55 (2), pp. 203-212.

Redder, A. (2017) 'Jeg ser ingen nationale løsninger.' Atlas, available at http://atlasmag.dk/samfund/jeg-ser-ingen-nationale-løsninger, accessed 12 March 2018.

Rosenblum, N. (2008) On the Side of the Angels: An appreciation of parties and partisanship. Princeton, NJ: Princeton University Press.

Rosenboim, O. (2017) The Emergence of Globalism. Princeton, NJ: Princeton University Press.

Scharpf, F. (2017) ‘De-constitutionalisation and majority rule: A democratic vision for Europe.' European Law Journal 23 (5), pp. 315-334.

Seville, A. (2017) There is No Alternative": Politik zwischen Demokratie und Sachzwang. Frankfurt am Main: Campus.

von Achenbach, J. (2017) 'The European Parliament as a Forum of National Interest? A Transnationalist Critique of Jürgen Habermas' Reconstruction of Degressive Proportionality.' Journal of Common Market Studies 55 (2), pp. 193-202.

Walker, N. (2007) 'Post-Constituent Constitutionalism? The Case of the European Union.' In M. Loughlin and N. Walker (eds.) The Paradox of Constitutionalism: Constituent Power and Constitutional Form. Oxford: Oxford University Press, pp. 247-268.

White, J. (2015) ‘Emergency Europe.' Political Studies 63(2), pp. 300-318.

White, J. and L. Ypi (2016) The Meaning of Partisanship. Oxford: Oxford University Press.

Wolkenstein, F. (2016) 'A Deliberative Model of Intra-Party Democracy.' Journal of Political Philosophy 24 (3), pp. 297-320.

Zúquete, J. P. (2015), 'The new frontlines of right-wing nationalism.' Journal of Political Ideologies 20 (1), pp. 69-85. 


\section{Recent LEQS papers}

Macchiarelli, Corrado 'What is the EU-UK relation all about? Tracking the path from monetary integration to "ever closeness"' LEQS Paper No. 137, September 2018

Meyer, Niclas 'EU break-up? Mapping plausible pathways into alternative futures' LEQS Paper No. 136, August 2018

Di Cataldo, Marco \& Monastiriotis, Vassilis 'An assessment of EU Cohesion Policy in the UK regions: direct effects and the dividend of targeting' LEQS Paper No. 135, June 2018

Innes, Abby 'First-best-world economic theory and the second-best-world of public sector outsourcing: the reinvention of the Soviet Kombinat by other means' LEQS Paper No. 134, May 2018

Bojar, Abel 'With a Little Help from My Friends: Ministerial Alignment and Public Spending Composition in Parliamentary Democracies' LEQS Paper No. 133, April 2018

Voss, Dustin "The Political Economy of European Populism: Labour Market Dualisation and Protest Voting in Germany and Spain" LEQS Paper No. 132, March 2018

Campos, Nauro F. \& Macchiarelli, Corrado "Symmetry and Convergence in Monetary Unions" LEQS Paper No. 131, March 2018

Costa Font, Joan \& Perdikis, Laurie 'Varieties of Health Care Devolution: "Systems or Federacies"?' LEQS Paper No. 130, February 2018

Calrsson, Ulrika "The Perennial Thirty Years' War" LEQS Paper No. 129, February 2018

Isiksel, Turkuler "Square peg, round hole: Why the EU can't fix identity politics" LEQS Paper No. 128, January 2018

Hancké, Robert \& Vlandas, Tim “The Politics of Disinflation” LEQS Paper No. 127, December 2017

White, Jonathan "Between Rules and Discretion: Thoughts on Ordo-liberalism" LEQS Paper No. 126, November 2017

Costa Font, Joan \& Zigante, Valentina "Building 'Implicit Partnerships'? Financial Long Term Care Entitlements in Europe" LEQS Paper No. 125, October 2017

Bohle, Dorothee "Mortgaging Europe's periphery" LEQS Paper No. 124, September 2017

Iordanoglou, Chrysafis \& Matsaganis, Manos "Why Grexit cannot save Greece (but staying in the Euro area might)" LEQS Paper No. 123, August 2017

Saka, Orkun "'Domestic banks as lightning rods? Home bias during the Eurozone crisis" LEQS Paper No. 122, February 2017

Coulter, Steve "Signalling Moderation: UK Trade Unions, 'New Labour' and the Single Currency" LEQS Paper No. 121, December 2016

Di Cataldo, Marco "Gaining and losing EU Objective 1 funds: Regional development in Britain and the prospect of Brexit" LEQS Paper No. 120, November 2016 


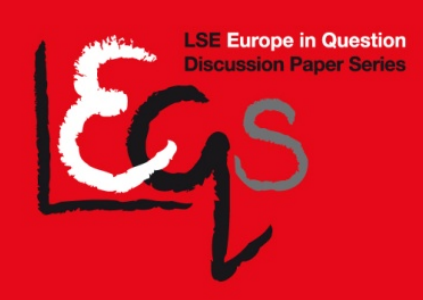

\section{LEQS}

European Institute London School of Economics Houghton Street WC2A 2AE London Email: euroinst.LEQS@Ise.ac.uk

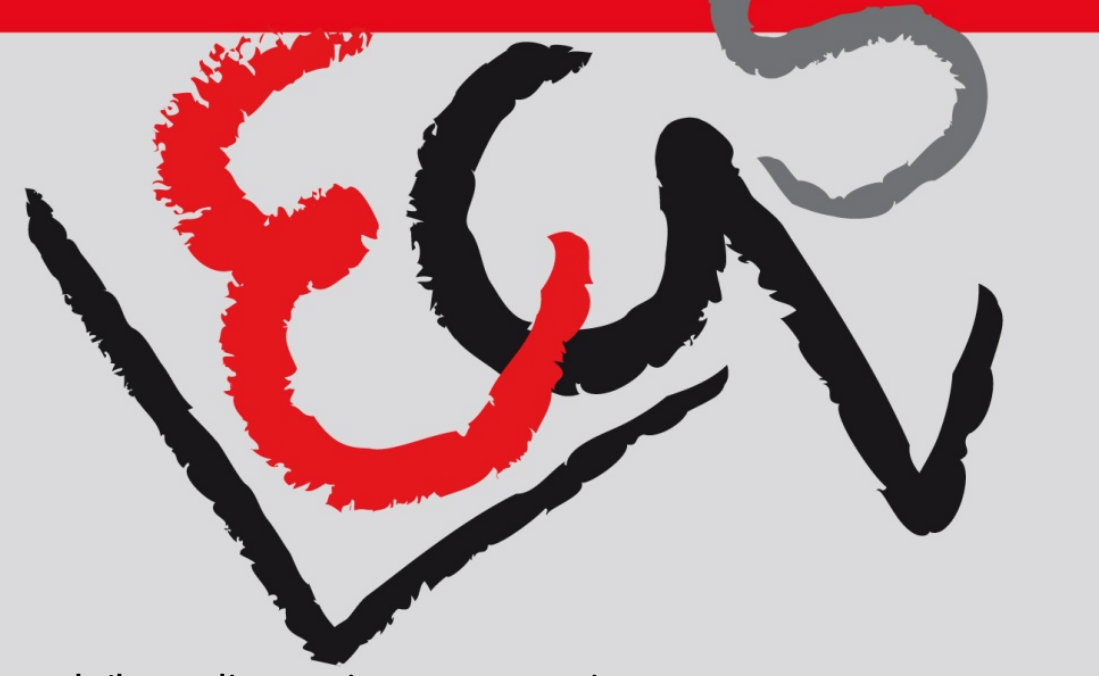

http://www.Ise.ac.uk/european-institute/research/leqs-discussion-paper-series 